\title{
INFORMASI KARAKTERISTIK MORFOMETRI DAS JANGKOK MENGGUNAKAN SISTEM INFORMASI GEOGRAFIS
}

\author{
Oleh: \\ Ega Denaswidhi \\ PEH Pertama pada BPDASHL Dodokan Moyosari Mataram
}

\begin{abstract}
Abstrak
Daerah Aliran Sungai (DAS) merupakan suatu kesatuan sistem lahan yang dibatasi oleh igir dan punggung gunung sebagai batas alami yang akan mengalirkan air curah hujan menjadi aliran permukaan atau aliran dasar menuju danau atau laut secara alami. Setiap DAS memiliki respon yang berbeda terhadap masukan curah hujan yang terjadi. Kondisi geomorfologi lahan DAS yang memberikan pengaruh terhadap kondisi hidrologi DAS, pada tahap awal dapat dianalisis dengan pendekatan morfometri DAS. Analisis informasi morfometri DAS dengan menggunakan pengukuran terestris di lapangan akan memerlukan tenaga, waktu dan biaya yang besar. Aplikasi Sistem Informasi Geografi s (SIG) saat ini sudah menjadi pilihan banyak pihak untuk memperoleh informasi morfometri DAS. Dalam studi ini DAS Jangkok dipilih sebagai lokasi studi karena DAS Jangkok memiliki variasi ekosistem yang beragam. Analisis untuk mendapatkan informasi nilai parameter mofometri DAS sangat penting dilakukan karena dapat dijadikan dasar untuk perencanaan atau kegiatan pengelolaan DAS. Parameter morfometri DAS Jangkok yang dianalisis dalam studi ini adalah luas, keliling, panjang dan lebar, kemiringan atau gradien alur, ketinggian rata-rata, orde percabangan sungai, kerapatan alur dan bentuk DAS. Metode yang digunakan dalam analisis ini adalah menurunkan informasi topografi maupun morfometri DAS secara otomatis pada perangkat lunak SIG. Berdasarkan hasil analisa yang dilakukan, diperoleh nilai morfometri DAS Jangkok berupa luas sebesar 17.243 hektar, panjang DAS mencapai 38,77 kilometer, kemiringan gradien alur sebesar 4,75 \%, terdapat 5 orde percabangan sungai dengan jumlah segmen aliran sebanyak 1.086 segmen. Bentuk DAS Jangkok cenderung memanjang dimana nilai indeks kebulatan DAS sebesar 0,23. SIG merupakan suatu sistem yang efektif untuk menurunkan informasi morfometri DAS.
\end{abstract}

Kata Kunci: Morfomoteri, Sungai Jangkok, SIG

\section{PENDAHULUAN}

Daerah Aliran Sungai (DAS) diartikan sebagai suatu wilayah daratan yang merupakan satu kesatuan dengan sungai dan anak-anak sungainya yang berfungsi menampung, menyimpan dan mengalirkan air yang berasal dari curah hujan ke danau atau laut secara alami, yang batas di darat merupakan pemisah topografis dan batas di laut sampai dengan daerah perairan yang masih terpengaruh aktivitas daratan. (Peraturan Pemerintah nomor 37/2012). Karena terbentuk dan dibatasi secara alami oleh batas topografi berupa igir, punggung bukit, dan lembah maka suatu daerah aliran sungai akan memberikan respon yang berbeda pada masukan air dalam hal ini curah hujan yang masuk pada wilayah DAS. Setiap DAS memliki karakteristik geofisik yang berbeda karena perbedaan topografi yang ada pada suatu daerah, hal ini berarti kondisi hidrologi pada DAS tersebut juga akan berbeda seperti kondisi debit aliran atau debit banjir, erosi hingga sedimentasi pada wilayah DAS tersebut.

Morfometri daerah aliran sungai adalah ukuran kuantitatif aspek geomorfologi suatu wilayah DAS yang merupakan faktor alami yang tidak dapat diubah oleh manusia dan berperan dalam memproses input curah hujan menjadi aliran permukaan. Kahirun, dkk. (2017) lebih jauh mengatakan bahwa karakteristik morfometri sangat menentukan perilaku air (hidrologi) suatu DAS seperti limpasan permukaan, infiltrasi, cadangan air tanah dan perilaku genangan banjir. Kejadian banjir yang akhir-akhir ini kerap terjadi selain pengaruh kondisi cuaca dan iklim juga dipengaruhi oleh morfometri DAS itu sendiri, misalnya dalam 
penentuan waktu konsentrasi aliran menjadi banjir dipengaruhi oleh bentuk DAS, panjang aliran dan kemiringan rata-rata DAS yang dapat diperoleh melalui analisa morfometri DAS. Aspek morfometri DAS bersifat statis dalam arti tidak dapat dirubah oleh aktifitasi manusia karena terbentuk dari proses geomorfologi lahan. Penilaian karakteristik morfometri DAS sangat penting dilakukan sebagai dasar pengelolaan wilayah berbasis DAS.

DAS Jangkok merupakan salah satu Daerah Aliran Sungai yang berada di pulau Lombok, Nusa Tenggara Barat. Wilayah alirannya melewati wilayah Kabupaten Lombok Barat dan Kota Mataram yang hulunya menjadi bagian dari gunung Rinjani. DAS Jangkok adalah salah satu DAS yang memiliki arti penting khususnya di Pulau Lombok karena memiliki ekosistem yang beragam didalamnya, mulai dari ekosistem pegunungan dengan kawasan hutan sebagai produsen air baku sampai ekosistem pesisir dan perkotaan di bagian hilir dimana aliran sungainya melewati kota Mataram sebagai pusat pemerintahan di Nusa Tenggara Barat. Oleh sebab itu penilaian morfometri DAS Jangkok menjadi bermanfaat untuk dasar pengelolaan DAS Jangkok secara lebih luas.

Ekstraksi informasi karakteristik Daerah Aliran Sungai dalam hal ini DAS Jangkok secara langsung menggunakan pengukuran terestris lapangan tentunya akan memerlukan tenaga, waktu dan biaya yang sangat besar, sehingga diperlukan suatu metode perolehan data morfometri DAS yang cepat dan mudah diaplikasikan. Saat ini hal tersebut dapat di akomodasi dengan penggunaan Sistem Informasi Geografis (SIG) dengan memanfaatkan citra penginderaan jauh berupa model elevasi digital (DEM) sebagai masukan data. Purwanto (2013), mengatakan bahwa dengan ketersediaan model elevasi permukaan bumi digital atau digital surface model (DSM) dan sistem informasi geografis (SIG), sifat DAS dapat diekstraksi dengan menggunakan prosedur otomatis. Data DEM dan perangkat lunak SIG saat ini mudah diperoleh secara daring sehingga semakin memudahkan masyarakat khususnya praktisi, akademisi dan perencana dalam suatu kegiatan pengelolaan DAS. Tulisan ini secara singkat akan membahas karateristik morfometri DAS Jangkok yang diturunkan dari pengolahan data DEM menggunakan perangkat lunak SIG.
Studi ini dimaksudkan untuk mengetahui karakteristik morfometri DAS Jangkok secara otomatis memanfaatkan perangkat lunak SIG yang bertujuan untuk memperoleh nilai parameter morfometri DAS berupa Luas dan Keliling DAS, Panjang dan lebar DAS, Kemiringan atau gradien sungai, ketinggain ratarata DAS, Orde sungai, kerapatan alur dan bentuk DAS.

\section{METODOLOGI PENELITIAN}

\section{a. Bahan Data}

Data yang digunakan dalam studi ini antara lain Citra Digital ASTER GDEM versi 2.0 wilayah Pulau Lombok dengan resolusi 30 meter dan Peta Batas DAS oleh Direktorat PEPDAS Kementerian Lingkungan Hidup dan Kehutanan (2018).

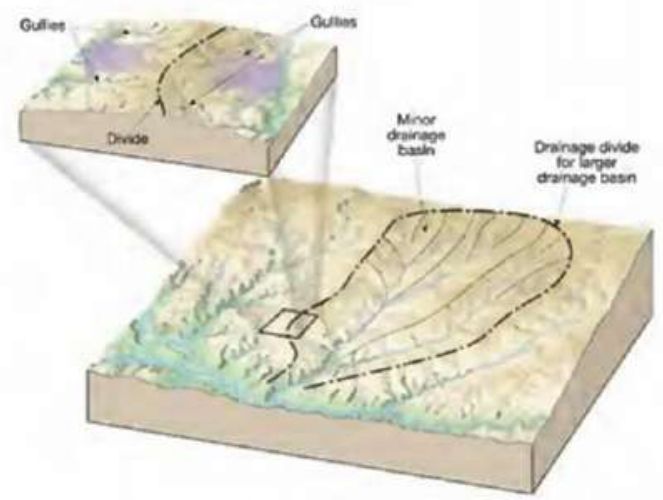

Gambar 1. Batasan suatu wilayah DAS (Purwanto, 2013)

\section{b. Lokasi Studi}

Lokasi kajian dalam studi ini adalah wilayah DAS Jangkok yang berada di Pulau Lombok pada koordinat (proyeksi UTM zona 50S) $397677 \mathrm{mT}$ - $431851 \mathrm{mT}$ dan $9070204 \mathrm{mU}$ $-9050593 \mathrm{mU}$.

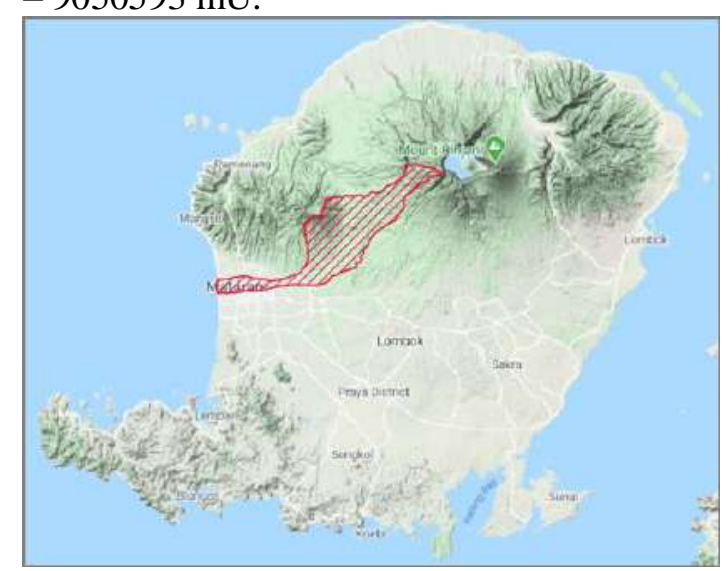

Gambar 2. Lokasi DAS Jangkok 


\section{Prosedur Kerja}

Parameter-parameter morfometri DAS Jangkok yang akan diturunkan dalam studi ini adalah Luas dan Keliling DAS; Panjang dan Lebar DAS; Kemiringan atau gradien sungai; Ketinggian rata-rata DAS; Orde atau tingkat percabangan sungai; Kerapatan aliran (alur) dan Bentuk DAS yang dijelaskan sebagai berikut.

\section{Luas dan keliling DAS}

Keliling DAS adalah panjang garis batas DAS yang merupakan punggung bukit atau gunung permukaan bumi dalam satuan meter atau kilometer $(\mathrm{km})$, sementara Luas DAS adalah area yang masuk dalam batas keliling DAS (dalam satuan $\mathrm{Ha}$ atau $\mathrm{km}^{2}$ )

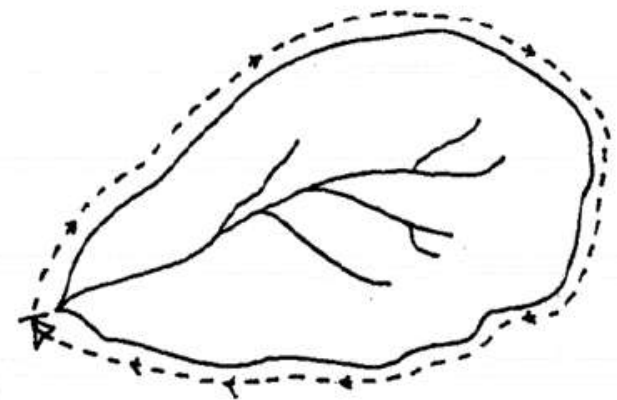

Gambar 3. Ilustrasi keliling DAS (Murtiono, 2001)

\section{Panjang dan Lebar DAS}

Panjang DAS adalah jarak terjauh yang diukur dari outlet sampai batas DAS di bagian hulu (satuan meter atau km) (Murtiono, 2001). Lebar DAS ditentukan dengan menggunakan rumus berikut (Seyhan,1977 dalam Purwanto, 2013)

$$
\begin{aligned}
& W=A / L b \\
& \text { Keterangan : } \\
& W=\text { lebar DAS }(\mathrm{km}) \\
& A=\text { luas DAS }(\mathrm{km} 2) \\
& \mathrm{Lb}=\text { panjang sungai utama }(\mathrm{km})
\end{aligned}
$$

\section{Kemiringan atau gradien sungai}

Gradien atau kemiringan sungai merupakan perbandingan beda tinggi antara hulu dengan hilir dan panjang sungai induk. Kemiringan alur sungai merupakan parameter dimensional yang menggambarkan besarnya penurunan rerata setiap jarak horizontal tertentu pada panjang sungai utama (Purwanto, 2013)

$$
S_{u}=\frac{\left(h_{\mathrm{*s}}-h_{10}\right)}{0,75 L b}
$$

$$
\begin{aligned}
\text { Keterangan }: & \\
\mathrm{Su}= & \text { Kemiringan alur sungai utama } \\
\mathrm{h} 10= & \text { Ketinggian titik yang terletak } \\
& \text { pada jarak } 0,10 \mathrm{Lb} \\
\mathrm{h} 85= & \text { Ketinggian titik yang terletak } \\
& \text { pada jarak } 0,85 \mathrm{Lb} \\
\mathrm{Lb}= & \text { Panjang alur sungai utama }
\end{aligned}
$$

\section{Ketinggian Rata-rata}

Ketinggian rata-rata DAS dihitung dengan metode kurva hipsometri, yang dibuat berdasarkan luas area antar dua garis kontur.

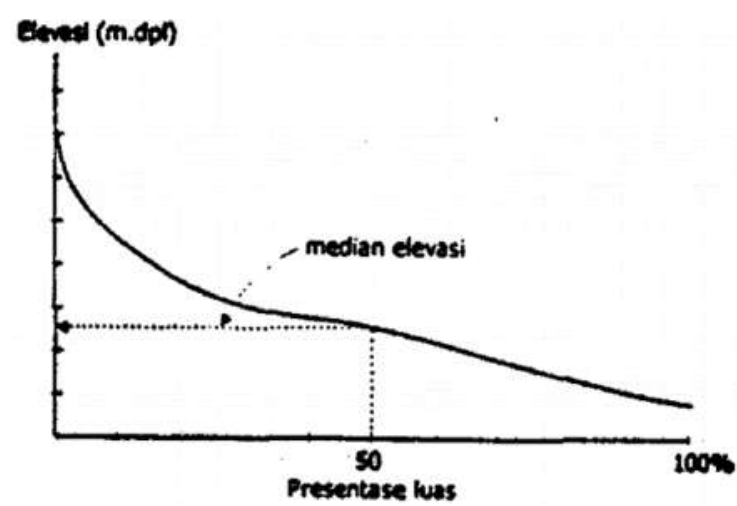

Gambar 4. Perhitungan ketinggan rata-rata dengan kurva hipsometri (Murtiono, 2001)

\section{Orde dan Tingkat Percabangan Sungai}

Orde sungai merupakan posisi percabangan alur sungai dalam urutannya terhadap sungai induk dalam suatu DAS (Murtiono, 2001). Banyak metode untuk menentukan orde sungai seperti Strahler, Horton, Shreve dan Scheidegger. Dalam studi ini digunakan metode Strahler karena lebih mudah diterapkan dan terintegrasi dengan berbagai perangakat lunak SIG saat ini.

Jumlah alur sungai suatu orde kemudian digunakan sebagai dasar untuk penentuan nilai indeks tingkat percabangan (bifurcation ratio) sungai melalui persamaan

$$
R b=\frac{N_{u}}{N_{u+1}}
$$

Sementara nilai tingkat percabangan sungai untuk suatu DAS ditentukan dengan menghitung tingkat percabangan sungai rata-rata tertimbang. 
$W_{R b}=\frac{\sum R b_{u i u+1}\left(N_{u}+N_{u+1}\right)}{N_{u}}$

Keterangan :

$\mathrm{Rb}=$ Indeks tingkat percabangan sungai

$\mathrm{N}_{\mathrm{u}}$ = Jumlah alur sungai untuk orde ke-u

$\mathrm{N}_{\mathrm{u}+1}=$ jumlah alur sungai untuk orde ke$(u+1)$

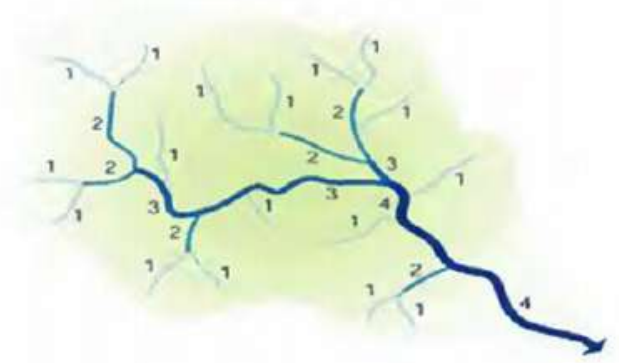

Gambar 5. Penentuan Orde sungai metode Strahler (Purwanto, 2013)

Nilai tingkat percabangan sungai dapat menggambarkan kondisi hidrologi suatu aliran sungai dalam suatu DAS dimana:

- $\mathrm{Rb}<3$, alur sungai memiliki kenaikan muka air banjir dengan cepat sedangkan penurunannya lambat

- $\mathrm{Rb} 3$ - 5, alur sungai memiliki kenaikan muka air banjir yang tidak terlalu cepat maupun terlalu lambat

- $\quad \mathrm{Rb}>5$, alur sungai mempunyai kenaikan muka air banjir yang cepat juga dengan penurunan muka air banjir yang cepat

\section{Kerapatan Alur}

Kerapatan aliran (alur) sungai adalah suatu angka indeks yang menunjukkan banyaknya anak sungai di dalam suatu DAS (Murtiono, 2001). Kerapatan aliran juga mencerminkan rerata panjang sungai terhadap luasan DAS. Untuk mendapatkan nilai indeks kerapatan aliran perlu diketahui panjang segmen masingmasing aliran pada setiap orde sungai. Kerapatan aliran diperoleh melalui persamaan :

$$
D d=\frac{L}{A}
$$

\section{Keterangan :}

$$
\begin{aligned}
& \text { Dd }=\text { kerapatan alur }\left(\mathrm{m} / \mathrm{km}^{2}\right) \\
& \text { Ln }=\text { total panjang alur }(\mathrm{m}) \\
& A=\text { luas DAS }\left(\mathrm{km}^{2}\right)
\end{aligned}
$$

Nilai indeks kerapatan alur kemudian diklasifikasikan sebagai berikut :

- $\quad$ Dd $<0,25 \mathrm{~km} / \mathrm{km}^{2}$ kategori Rendah

- $\quad$ Dd 0,25-10 km/ $\mathrm{km}^{2}$ kategori Sedang

- Dd $10-25 \mathrm{~km} / \mathrm{km}^{2}$ kategori Tinggi

- Dd $>25 \mathrm{~km} / \mathrm{km}^{2}$ kategori Sangat Tinggi

Berdasarkan batasan nilai klasifikasi ini, Murtiono (2001) menjelaskan bahwa :

- Nilai Dd Rendah, alur sungai melewati batuan dengan resistensi keras, maka angkutan sedimen yang terangkut aliran sungai lebih kecil bila dibandingkan pada alur sungai yang melewati batuan dengan resistensi lebih lunak apabila kondisi lain yang mempengaruhinya sama

- Nilai Dd Tinggi, alur sungainya melewati batuan yang kedap air, keadaan ini akan menunjukan bahwa air hujan yang menjadi aliran akan lebih besar jika dibandingkan suatu daerah dengan $\mathrm{Dd}$ rendah melewati batuan yang permeabilitasnya besar.

\section{Bentuk DAS}

Bentuk DAS memiliki arti penting dalam hubunganya dengan aliran sungai yaitu berpengaruh terhadap kecepatan terpusatnya aliran. Secara kuantitatif bentuk DAS sulit untuk ditentukan karena memilki yang tidak beraturan karena pengaruh batas alam. Pendekatan nisbah (indeks) kebulatan (circularity ratio) menggunakan persamaan

$$
R c=\frac{4 \pi A}{P^{2}}
$$

\section{Keterangan :}

$$
\begin{aligned}
& \mathrm{Rc}=\text { nisbah kebulatan } \\
& \mathrm{A}=\text { luas DAS }(\mathrm{km} 2) \\
& \mathrm{P}=\text { keliling (perimeter) DAS }(\mathrm{km})
\end{aligned}
$$

Secara sederhana nilai indeks kebulatan $(\mathrm{Rc})>$ 0,5 maka suatu DAS dikatakan berbentuk membulat dan nilai Rc $<0,5$ maka DAS tersebut cenderung memiliki bentuk memanjang atau berbentuk daun.

Bentuk DAS yang lebih bulat memiliki waktu konsentrasi aliran yang lebih cepat dibandingkan DAS berbentuk memanjang karena itu DAS yang memiliki bentuk membulat memilki resiko kejadian banjir lebih tinggi

\section{Pengolahan Data}


Data citra digital ASTER GDEM versi 2.0 resolusi 90 meter wilayah pulau Lombok yang memiliki informasi model ketinggian digunakan dalam studi ini dengan Peta Batas DAS yang dikeluarkan oleh Direktorat PEPDAS sebagai acuan penarikan batas DAS Jangkok.

Berdasarkan peta Batas DAS kemudian data citra ASTER GDEM dilakukan proses Cropping untuk mendapatkan area DAS Jangkok sebagai daerah kajian dalam studi ini.

Selanjutnya dilaukan proses penyesuaian proyeksi peta menggunakan proyeksi Universal Transverse Mercator (UTM) dimana untuk wilayah Nusa Tenggara Barat berada pada zona 50. Penyesuaian proyeksi menggunakan proyeksi UTM dalam studi ini dimaksudkan agar pengolahan data citra maupun peta menjadi lebih mudah karena menggunakan satuan jarak (meter) sebab proyeksi UTM merupakan salah satu sistem proyeksi yang menggunakan basis jarak.

Proses selajutnya adalah aplikasi fungsi Fill sink untuk data DEM yang digunakan. Fungsi fill sink menghilangkan depression atau sink yaitu kondisi dimana terdapat perbedaan elevasi yang mencolok dengan cakupan yang sangat kecil, untuk pengolahan data dalam lingkup hidrologi hal ini dapat mengganggu perhitungan maka perlu dihilangkan terlebih dahulu (Purwanto, 2013).

Selanjutnya data ASTER GDEM dapat digunakan untuk penentuan ketinggian dan informasi topografis dengan menggunakan perangkat lunak SIG dalam hal ini penulis menggunakan Quantum GIS versi 3.4

Penghitungan parameter morfometri lanjutan menggunakan perangkat lunak pengolah angka setelah diperoleh data yang diperlukan.

\section{HASIL DAN PEMBAHASAN}

Karakterisik morfometri DAS Jangkok melalui pengolahan data citra digital ASTER GDEM versi 2.0 dapat dilakukan menggunakan perangkat lunak SIG saat ini, sehingga perolehan data informasi mengenai DAS akan lebih mudah dilakukan.

Luas DAS Jangkok yang diperoleh dengan perhitungan otomatis geometri batas DAS adalah sebesar 17.243,02 hektar. Luasan DAS Jangkok termasuk dalam DAS kecil menurut kriteria klasifikasi DAS yaitu termasuk diantara $10.000-100.000$ hektar. Hal ini tidak terlepas dari kondisi geografis DAS Jangkok yang merupakan bagian dari DAS Kepulauan yang rata-rata memiliki kriteria sangat kecil sampai sedang. Keliling DAS Jangkok secara keseluruhan mencapai 96,32 kilometer.

Panjang DAS Jangkok dari outlet DAS sampai kebagian hulu DAS mencapai 38,77 kilometer. Perhitungan panjang DAS tidak termasuk aliran sungai pada badan DAS dan merupakan perhitungan jarak datar. Sementara lebar DAS yang dihitung dengan persamaan lebar DAS (W) mencapai 5,08 kilometer. Lebar DAS tidak menggambarkan lebar DAS per segmen DAS tetapi merupakan rata-rata dari keseluruhan wilayah DAS Jangkok. Seperti dapat dilihat pada gambar wilayah DAS Jangkok cenderung menyempit dan memanjang pada bagian tengah sampai hilir.

Kemiringan atau gradien sungai DAS Jangkok diperoleh dari perhitungan beda tinggi pada sungai utama. Penggunaan citra DEM mempermudah perolehan informasi ketinggaian aliran karena masing - masing piksel pada citra DEM mempresentasikan ketinggian suatu wilayah. Panjang aliran utama (Lb) DAS Jangkok adalah 33,94 kilometer yang diturunkan dari segmen percabangan sungai pada DAS Jangkok. Ketinggian pada 85 persen panjang alur utama $1.246 \mathrm{mdpl}$ sementara ketinggian 10 persen panjang alur utama di bagian hilir pada ketinggian $37 \mathrm{mdpl}$. Dengan pengolahan data dari nilai masing ketinggian pada 85 persen dan 10 persen panjang alur utama diperoleh gradien sungai DAS Jangkok sebesar 0,0475 atau 4,75 $\%$. Nilai gradien sungai DAS Jangkok menunjukkan penurunan rerata pada setiap segmen panjang sungai tidak terlalu tinggi.

Tabel 1. Perbandingan luas kumulatif pada setiap perbedaan ketinggian di DAS Jangkok

\begin{tabular}{|l|r|r|r|}
\hline Elevasi (mdpl) & Luas (Ha) & Luas (\%) & Kumulatif \\
\hline $0-200$ & $3,145,68$ & 18,24 & 100,00 \\
\hline $200-400$ & $3.122,75$ & 18,11 & 81,76 \\
\hline $400-600$ & $3.003,63$ & 17,42 & 63,65 \\
\hline $600-800$ & $3.296,80$ & 19,12 & 46,23 \\
\hline $800-1000$ & $1,811,97$ & 10,51 & 27,11 \\
\hline $1000-1200$ & 969,18 & 5,62 & 16,60 \\
\hline $1200-1400$ & 449,82 & 2,61 & 10,98 \\
\hline $1400-1600$ & 353,24 & 2,05 & 8,37 \\
\hline $1600-1800$ & 340,63 & 1,98 & 6,32 \\
\hline $1800-2000$ & 252,65 & 1,47 & 4,35 \\
\hline $2000-2200$ & 187,62 & 1,09 & 2,88 \\
\hline $2200-2400$ & 172,74 & 1,00 & 1,79 \\
\hline $2400-2600$ & 93,07 & 0,54 & 0,79 \\
\hline $2600-2800$ & 43,24 & 0,25 & 0,25 \\
\hline
\end{tabular}


Ketinggian rata-rata DAS Jangkok yang di analisis menggunakan kurva hipsometrik berada pada ketinggian 800 mdpl. Hubungan akumulasi luas DAS pada setiap perbedaan ketinggian pada DAS Jangkok seperti pada tabel 1.

Dari tabel 1 dapat dilihat pada wilayah DAS Jangkok, daerah dengan ketinggian diatas 800 mdpl tidak lebih dari 27,11 persen luas wilayah DAS Jangkok. Hal ini juga berkaitan dengan gradien kemiringan alur DAS Jangkok yang tidak terlalu besar. Perbedaan ketinggian rata-rata DAS Jangkok juga dapat dilihat pada kurva hipsometri DAS Jangkok.

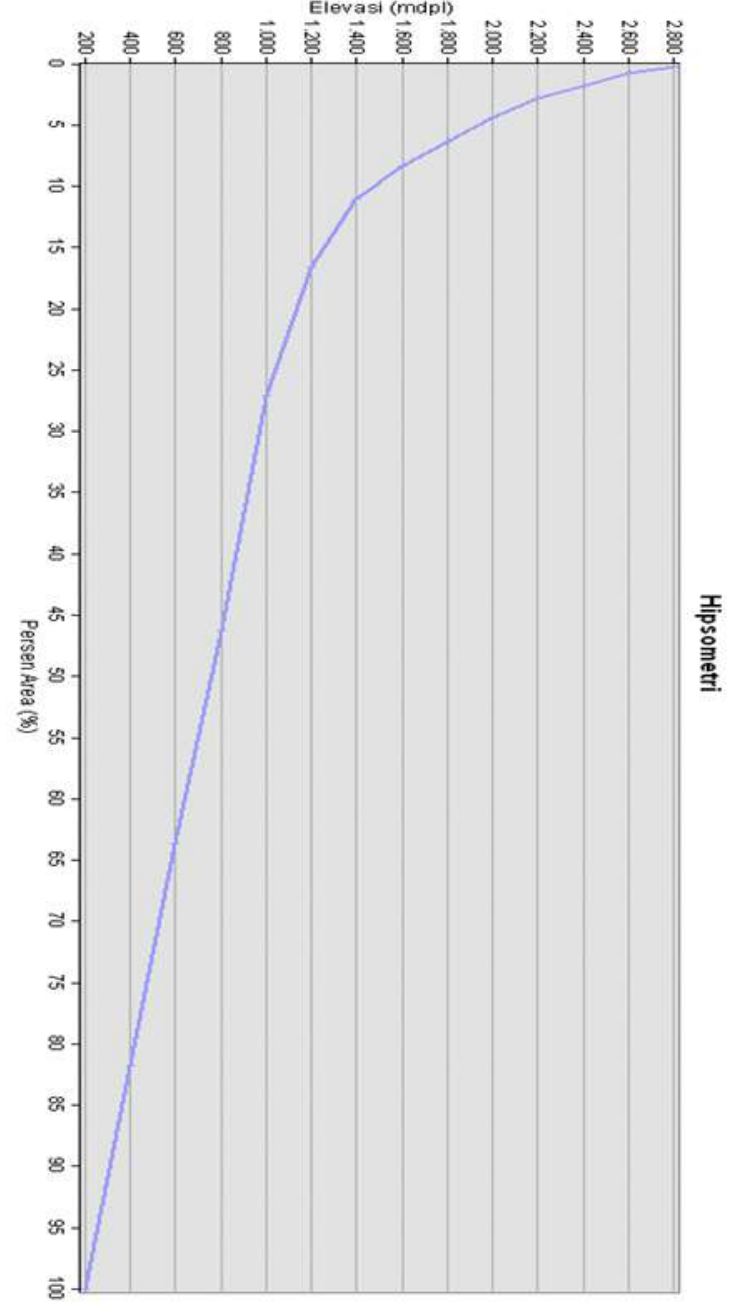

Gambar 6. Kurva hipsometri DAS Jangkok

Orde percabangan sungai pada wilayah DAS Jangkok diperoleh sebanyak 5 orde pada metode Strahler dimana jumlah panjang segmen dari semua ordo mencapai 481.002,1 meter dengan jumlah segmen sebanyak 1.086 segmen aliran. Hasil analisis indeks percabangan sungai tertimbang (WRb) di DAS Jangkok sebesar 2,06 yang dapat diartikan bahwa pada wilayah DAS Jangkok kenaikan muka air banjir akan cepat dengan penurunan yang lambat, hal ini dapat menjadi langkah awal dalam pengelolaan DAS terutama untuk mitigasi bencana banjir. Tingkat percabangan sungai pada DAS Jangkok seperti dapat dilihat pada Tabel 2.

Tabel 2. Orde percabanan sungai pada DAS Jangkok

\begin{tabular}{|c|r|r|r|}
\hline Orde & \multicolumn{1}{|c|}{$\begin{array}{c}\text { Jumlah } \\
\text { Segmen }\end{array}$} & $\begin{array}{c}\text { Panjang } \\
\text { Segmen Orde } \\
(\mathrm{m})\end{array}$ & $\begin{array}{r}\text { Biforcation } \\
\text { Ratio }(\mathrm{Rb})\end{array}$ \\
\hline 1 & 568 & $241.315,00$ & 2,33 \\
\hline 2 & 244 & $123.679,00$ & 1,52 \\
\hline 3 & 161 & 69.037 .40 & 2.30 \\
\hline 4 & 70 & $29.740,90$ & 1.63 \\
\hline 5 & 43 & $17.229,80$ & \\
\hline & 1.086 & $481.002,10$ & \\
\hline
\end{tabular}

Berdasarkan informasi data panjang aliran pada DAS Jangkok kemudian dapat terhitung kerapatan aliran pada DAS Jangkok. Nilai kerapatan aliran pada DAS Jangkok sebesar 2,79 $\mathrm{km} / \mathrm{km}^{2}$, masuk ke dalam kategori sedang artinya alira air pada wilayah DAS Jangkok melewati batuan dengan resistensi tidak terlalu tinggi sehingga muatan sedimen yang kemungkinan terangkut cukup tinggi.

Bentuk DAS Jangkok berdasarkan analisis indeks kebulatan (Rc) adalah memanjang dimana nilai Rc diperoleh sebesar 0,23. Dengan bentuk DAS yang memanjang waktu konsentrasi aliran pada wilayah DAS Jangkok tidak terlalu cepat untuk menjadi suatu aliran banjir dengan memperhatikan kondisi curah hujan dan gradien kemiringan DAS Jangkok. Bentuk DAS Jangkok yang memanjang juga dapat dikaitkan dengan lebar DAS (W) seperti telah disampaikan diatas, bahwa rata-rata lebar DAS secara keseluruhan memang tidak terlalu tinggi.

Nilai kuantitatif untuk mengukur parameter - parameter morfometri DAS Jangkok dapat diturunkan dari data citra digital DEM dan Sistem Informasi Geografis sehingga dapat diperoleh gambaran umum kondisi DAS Jangkok dari aspek morfologi lahan DAS untuk kebutuhan perencanaan lebih lanjut misalnya analisis penggunaan lahan, analisis hidrologi DAS, penentuan kesesuaian lahan untuk suatu pemanfaatan tertentu dan mitigasi bencana terutama banjir dan tanah longsor. Lebih jauh, dengan penggunaan SIG penggambaran suatu DAS dapat divisualisasikan secara 3 Dimensi untuk memberikan pemahaman yang lebih mudah pada masyarakat yang belum mengenal konsep DAS secara mudah. Gambaran umum 
morfometri DAS Jangkok dapat dilihat pada Tabel 3.

Tabel 3. Parameter Morfometri DAS

\begin{tabular}{|l|l|r|l|}
\hline \multicolumn{2}{|c|}{ Parameter Morfometri DAS } & Nilai & Satuan \\
\hline Luas DAS & A & 172,43 & $\mathrm{~km} 2$ \\
\hline Keliling DAS & P & 96,32 & $\mathrm{~km}$ \\
\hline Panjang DAS & Ln & 38,77 & $\mathrm{~km}$ \\
\hline Lebar DAS & W & 5,08 & $\mathrm{~km}$ \\
\hline Panjang Alur utama & Lb & 33,94 & $\mathrm{~km}$ \\
\hline Gradien Kemiringan DAS & So & 4,75 & $\%$ \\
\hline Jumlah Segmen Alur & & $1.086,00$ & - \\
\hline Percabangan sungai & WRb & 2,06 & - \\
\hline Kerapatan Alur & Dd & 2,79 & $\mathrm{~km} / \mathrm{km} 2$ \\
\hline Indeks Bentuk DAS & Rc & 0,23 & - \\
\hline
\end{tabular}

Sumber: Pegolahan Data (2020)

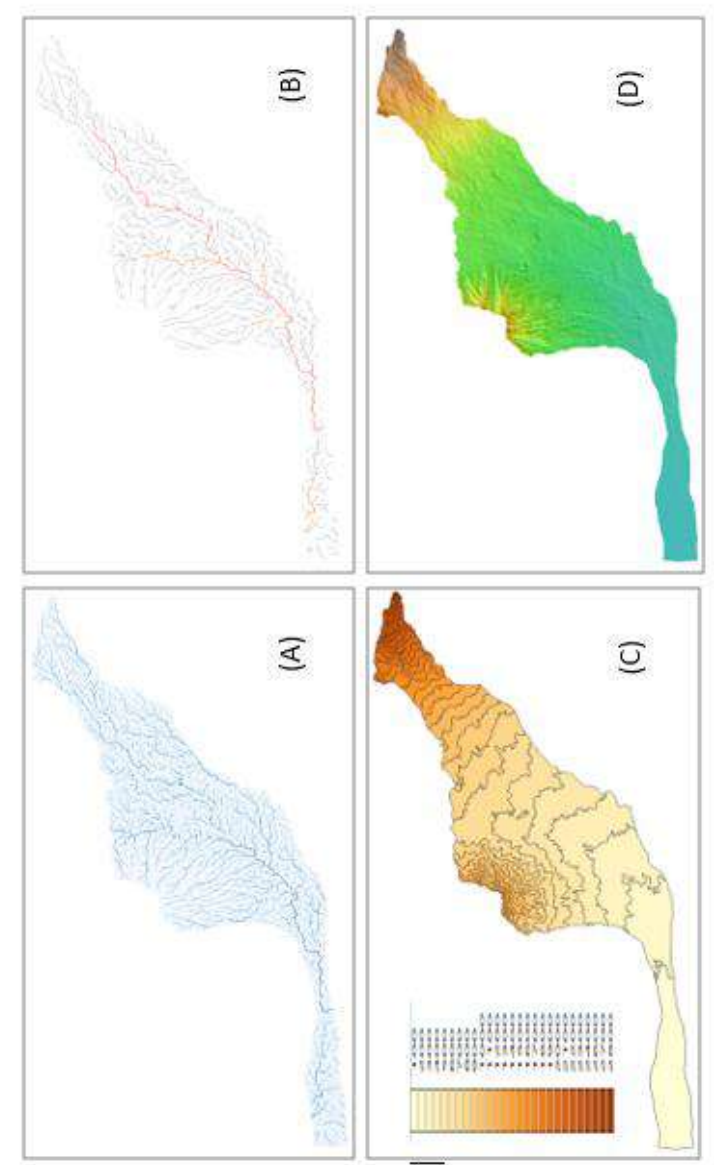

Gambar 7. Hasil Pengolahan SIG untuk analisis morfometri DAS Jangkok: (A) Orde sungai dengan metode Strahler; (B) Aliran pada DAS Jangkok; (C) Topografi DAS Jangkok; (D) Topografi DAS Jangkok dengan menggunakan hillshading

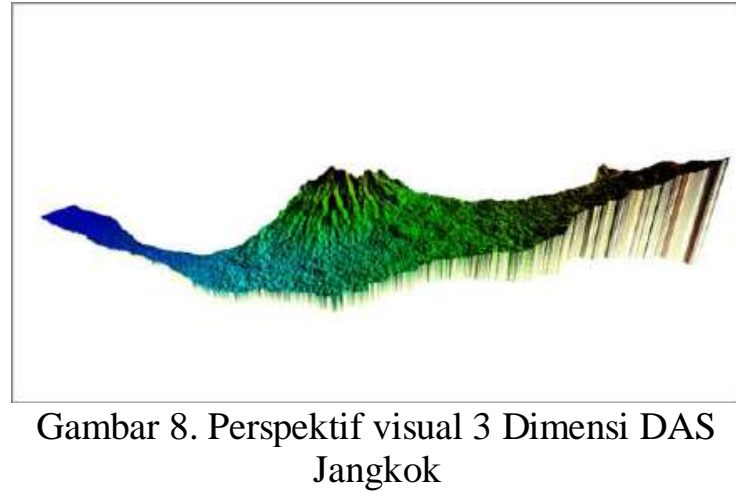

\section{KESIMPULAN}

Hasil analisis morfometri DAS Jangkok dari data digital ASTER GDEM dengan menggunakan SIG dapat diperoleh kesimpulan sebagai berikut :DAS Jangkok merupakan DAS kecil dengan luas area 17.243,02 ha dengan ketinggian rata-rata DAS 800 mdpl dan panjang alur sungai utama sepanjang 33,94 kilometer. Terdapat 1.086 segmen alur dengan total panjang mencapai 481 kilometer. Bentuk DAS Jangkok adalah memanjang berdasarkan pendekatan indeks kebulatan yang memiliki nilai 0,23. Kerapatan alur sungai pada DAS Jangkok masuk kategori sedang dengan nilai kerapatan alur $2,79 \mathrm{~km} / \mathrm{km}^{2}$. Sistem informasi Geografis (SIG) merupakan suatu sistem yang efektif dan mudah digunakan dalam menurunkan informasi morfometri DAS dari data digital citra DEM untuk suatu kegiatan perencanaan maupun pengelolaan DAS lebih lanjut.

\section{DAFTAR PUSTAKA}

Dulbahri. 2004. Peran Penginderaan Jauh Dalam Pengelolaan Daerah Aliran Sungai. Sains Informasi Geografis: Dari Perolehan dan Analisis Citra Hingga Pemetaan dan Pemodelan Spasial. Yogyakarta : Jurusan Kartografi dan Penginderaan Jauh, Fakultas Geografi UGM

Hambali, Rizki. 2017. Analisis Hubungan Bentuk DAS Dengan Debit Banjir Studi Kasus: DAS Kali Pesanggrahan, DAS Kali Krukut Dan DAS Kali Cipinang. Faktor Exacta 10 (4). 389-400

Kahirun, dkk. 2017. Karakteristik Morfometri Menentukan Kondisi Hidrologi DAS Roraya. Ecogreen. Vol. 3 No. 2 
Murtiono, Ugro Hari. 2001. Pedoman Teknis Pengukuran dan Perhitungan Parameter Morfometri DAS. Surakarta: BTPDAS

Peraturan Pemerintah Nomor 37 Tahun 2012 Tentang Pengelolaan Daerah Aliran Sungai.

Purwanto, Taufik Hery. 2013. Ekstraksi Morfometri Daerah Aliran Sungai Dari Data Digital Surface Model (Studi Kasus DAS Opak). Yogyakarta

Soewarno. 1991. Hidrologi, Pengukuran dan Pengelolaan Data Aliran Sungai (Hidrometri). Bandung: Nova 